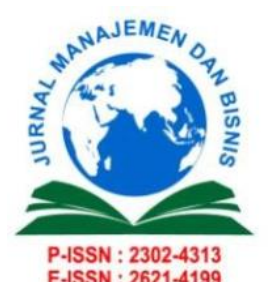

Jurnal Manajemen dan Bisnis

Vol. 10, No. 1, Juni 2021, pp. 48- 61

Sekolah Tinggi Ilmu Ekonomi Indragiri (STIE-I) Rengat

https://journal.stieindragiri.ac.id/index.php/jmbi/issue/view/17

\title{
THE EFFECT OF ORGANIZATIONAL CULTURE, LEADERSHIP \\ STYLE, KNOWLEDGE MANAGEMENT, WORK DISCIPLINE, AND WORK ENVIRONMENT ON EMPLOYEE SATISFACTION \\ PBEC EYE HOSPITAL
}

Agus Taufiq ${ }^{1)}$, Isyandi' ${ }^{2}$, Yusni Maulida ${ }^{3)}$

1) Students of the Riau University Postgraduate Program

2) 3) Lecturer at the Postgraduate Program at the University of Riau

1) agustaufiq97@gmail.com

Submited: 2021.03.29 Reviewed: 2021.06.22 Accepted: 2021.08.08

https://doi.org/10.34006/jmbi.v10i1.251

\begin{abstract}
This study aims to analyze the influence of organizational culture, leadership style, knowledge management, work discipline, and work environment on job satisfaction of employees of Pekanbaru Eye Center Eye Center. The data of this study consisted of primary and secondary data, which were taken through a questionnaire to 81 employees of the Pekanbaru Eye Center Eye Center with a sample census. The variables used are organizational culture, leadership style, knowledge management, work discipline and work environment as independent variables and job satisfaction as the dependent variable. The data obtained were processed using SmartPLS.

The results of this study indicate that organizational culture, leadership style and work environment have a positive and significant effect on employee job satisfaction. Knowledge management has a negative effect on employee job satisfaction, and work discipline does not have a significant effect on employee job satisfaction.

Keywords : Job Satisfaction, organizational culture, leadership style, knowledge management, work discipline, work environment.

\section{Preliminary}

Hospital is an organization engaged in health services. The growth of the hospital and the demands of the times, demands the hospital to improve its performance and provide the best service for patients. The function of hospitals today is increasing towards comprehensive health services in line with the development of science and technology both in healing efforts for people who are sick and for patients who need health consultations and efforts to improve health. Hospitals must have good performance to exist and excel in the competition.

Hospital is a health service institution that has a vision, mission and goals to be achieved, which greatly affects its ability to manage human resources so that optimal service quality is created. The quality of health services produced by the hospital is strongly influenced by the performance of its employees.

Based on Law Number 44 of 2009 concerning Hospitals, article 29 paragraph (b), Hospitals are obliged to provide safe, quality, anti-discrimination and effective health services by prioritizing the interests of patients in accordance with Hospital service standards, Hospitals are obliged to make , implement and maintain health service quality standards in hospitals as a reference in serving patients.
\end{abstract}


Pekanbaru Eye Center Hospital (PBEC) as one of the special eye hospitals operating in Pekanbaru City always tries to improve its performance in providing services to the community. To be able to do this, the Pekanbaru Eye Center (PBEC) Eye Hospital evaluates the performance of employees both medical and non-medical staff who work at PBEC Eye Hospital as a reference to improve service quality and reduce the impact of patient demands. The results of the performance evaluation of the PBEC Eye Hospital employees are shown in table 1

Table 1 Results of Employee Performance Evaluation of PBEC Eye Hospital in 2017-2019

\begin{tabular}{|c|c|c|c|c|c|c|c|}
\hline $\begin{array}{c}\text { No } \\
\cdot\end{array}$ & Category & $\begin{array}{c}\mathbf{2 0 1} \\
\mathbf{7}\end{array}$ & $\mathbf{\%}$ & $\mathbf{2 0 1 8}$ & $\mathbf{\%}$ & $\mathbf{2 0 1 9}$ & $\mathbf{\%}$ \\
\hline 1 & $\begin{array}{c}\text { Very } \\
\text { good }\end{array}$ & 9 & 15.5 & 8 & 12.3 & 5 & 7.0 \\
\hline 2 & Good & 27 & 46.6 & 38 & 58.5 & 25 & 35.2 \\
\hline 3 & $\begin{array}{c}\text { Pretty } \\
\text { good }\end{array}$ & 15 & 25.9 & 17 & 26.1 & 33 & 46.5 \\
\hline 4 & Not good & 7 & 12 & 2 & 3,1 & 8 & 11.3 \\
\hline \multicolumn{2}{|c}{ amount } & $\mathbf{5 8}$ & $\mathbf{1 0 0}$ & $\mathbf{6 5}$ & $\mathbf{1 0 0}$ & $\mathbf{7 1}$ & $\mathbf{1 0 0}$ \\
\hline
\end{tabular}

Source: PBEC Eye Hospital 2019

From Table 1, the results of the employee performance evaluation at PBEC Eye Hospital can be seen from year to year there has been a decline in employee performance. This shows the need for an evaluation to find out what causes the decline in employee performance and what is done to improve employee performance. A decrease in employee performance can lead to a decrease in hospital performance.

Company performance is influenced by employee performance. Employee performance is strongly influenced by employee job satisfaction. Kemployees who are satisfied with their work tend to work harder and better than employees who are not satisfied with their work. To determine the level of satisfaction of employees of PBEC Eye Hospital, the authors conducted a pre-survey of 20 employees of the PBEC Eye Hospital. Where a score of 1 indicates very dissatisfied (STP), a score of 2 is not satisfied (TP), a score of 3 is neutral $(\mathrm{N})$, a score of 4 is satisfied $(\mathrm{P})$, and a score of 5 is very satisfied (SP). The pre-survey results shown in table 1.2 show that there are problems with employee job satisfaction.

From the results of the pre-survey, the total score for the level of employee satisfaction was 394 with 9 statements, so that the PBEC Eye Hospital employee satisfaction score from the pre-survey results was 43.8, which was in the dissatisfied category, and from the table it was also seen that $67.3 \%$ of employees were dissatisfied with his current working conditions.

Job satisfaction is a general attitude of an individual to his job. Each individual has a different level of satisfaction according to the value system that applies to him. The more aspects that are in accordance with the desires of the individual, the higher the job satisfaction. From this description, it can be said that job satisfaction is a person's feelings towards his job by considering the aspects that are in his job so that there arises in him a feeling of pleasure or displeasure with work situations and colleagues. What the individual feels can be positive or negative depending on the perception of the work being done.

Robbins and Judge (2015)said that job satisfaction is a positive feeling about the job, which results from an evaluation of its characteristics. A person with a high level of job satisfaction has positive feelings about his job, while someone with a low level of satisfaction has negative feelings. 
Job satisfaction is a pleasant emotional attitude and loves his job. This attitude is reflected in work morale, discipline, and work performance(Isyandi, 2017).

Job Satisfaction Indicator according to Schermerhorn JR. et.al inIsyandi (2017) stated, satisfaction can be measured in five phases of satisfaction, namely the work itself, the quality of supervision, promotion, wages or salaries, and the people who work.

One of the factors that influence job satisfaction is organizational culture. According to Edgar Schein inIsyandi (2017)states that organizational culture is a basic assumption created or developed by certain groups when they adjust to external problems and internal integration that have worked quite well and are considered valuable, and are therefore taught to new members as the correct way to realize, think, and feel a connection to the problem.

Schein divides organizational culture into three levels. (1) Artifacts, which are the outermost and visible elements of organizational culture. Artifacts are a reflection of the basic values and assumptions adopted by the organization, including the Hospital logo, hospital slogans, layout, and other symbols. (2) Values (values) are a basic element of organizational culture that directs the behavior of its members. Values are related to morals, which play a role in determining what should be done. A person who adheres to the value of safety will behave in accordance with the values he adheres to because it is considered something right. (3) Basic assumptions are the deepest part (philosophy) of the organizational culture that underlies the attitudes, beliefs and values of its members, for example work is worship.

Furthermore, the factor that affects job satisfaction is leadership. According toRobbins and Judge (2015) leadership is the ability to influence a group towards the achievement of a goal. Leadership is a person who is carried out in certain situations, and is directed through a communication process towards the achievement of one or several specific goals. Leadership involves the process of social influence that is deliberately carried out by a person on another to structure activities and influence within a group or organization.

Broadly speaking, the definition of leadership refers to three things (Isyandi, 2017), namely: (1) Emphasizing the personality, abilities and abilities of the leader. (2) Emphasize the activities, position and behavior of the leader. (3) Emphasizes the interaction process between leaders and subordinates in certain situations. This definition illustrates that the leadership process is a function of the leader, followers, and the situation.

The leadership style is a determining factor for the success and sustainability of an organization. Leadership has the authority that can be used at any time to solve a problem concerning the organization. So that we need a qualified leader, who is able to answer challenges and problems in the organization in an effort to achieve good employee performance.

Leadership style is behavior and strategy as a result of a combination of philosophies, skills, traits and attitudes that are often applied by a leader because he tries to influence the performance of his subordinates. The leadership style used by the leadership will affect the success of the leadership, through the authority and authority they have in achieving an organizational goal they lead. This condition can affect the performance achieved by employees. So that a portrait of a leader can be seen from the performance of his subordinates.

Furthermore, the factor that affects job satisfaction is knowledge management. According toZhou and Fink (2003)said that knowledge management is managing organizational processes to create, store and reuse organizational knowledge. Knowledge management is a system designed to create, document, classify, and disseminate knowledge within the organization. Thus, knowledge is easy to use whenever needed, by anyone according to their level of authority and competence. 
Horwitch and Armacost inside Sangkala (2007) defines knowledge management as the implementation of creating, capturing, transferring, and accessing appropriate knowledge and information when needed to make better decisions, act appropriately, and provide results in support of business strategy.

Davidson and Voss in Sangkala (2007) defines knowledge management as a system that allows companies to absorb knowledge, experience, and creativity in their staff for the improvement of company performance.

From the definitions of knowledge management above, it can be concluded that knowledge management is a knowledge-based management process, the goal of which is how to create a means and a supportive environment for the process of creation, dissemination, application and protection of knowledge within an organization. Knowledge management is a systematic effort to encourage and facilitate the flow of knowledge between elements within an organization so that it can accelerate the organizational learning process.

Knowledge (knowledge) is divided into two types, namely: (1) Tacit knowledge, is knowledge obtained from experience, activities carried out and has been defined which are usually shared through discussions and stories. (2) Explicit knowledge, is knowledge that has been formulated, usually presented in written form, for example regulations, books, and literature.

And the last factor that affects satisfaction is discipline. According to Keith Davis inMangkunegara (2013) stated, work discipline can be interpreted as the implementation of management to reinforce organizational guidelines. Hasibuan (2018)stating discipline is the awareness and willingness of a person to obey all company regulations and applicable norms. Awareness is the attitude of a person who voluntarily obeys all the rules and is aware of his duties and responsibilities, so he will obey / do all his duties properly, not by force. Meanwhile, what is meant by willingness is an attitude, behavior and actions of a person in accordance with company regulations, whether written or not.

According to Wake up (2012), one of the organizational resources that has an important role in achieving its goals is human resources. One of the most influential factors in human resources is the discipline factor. For organizations, the existence of work discipline will ensure that order is maintained and the execution of tasks is smooth, so that optimal results are obtained.

Work discipline is an attitude of respecting, appreciating, and obeying the applicable rules, both written and unwritten and being able to carry it out, not evading with sanctions if it violates the duties and authorities given to it.

According to Jain and Kaur (2014) states the work environment as a condition that includes physical, psychological, and social aspects that improve working conditions. Rivai and Mulyadi (2012) describes the work environment, namely organizational elements as a social system that has a strong influence in shaping individual behavior in the organization and affects organizational performance.

According to Sedarmayanti (2011) The work environment can be divided into two types, namely:

1. Physical work environment, physical work environment is all physical conditions that exist around the workplace that affect employees. The physical work environment is divided into two categories, namely: (1) The work environment is directly related to employees such as work centers, chairs, tables, and so on, (2) Intermediary environments that affect the human condition such as temperature, humidity, air circulation, lighting, noise, vibration mechanics, unpleasant odors, colors and so on. To be able to minimize the influence of the physical environment on employees, the first step should be to study humans, both physically and their 
behavior, then use it as a basis for thinking about the appropriate physical environment.

2. Non-physical work environment, includes all circumstances related to work relationships, both relationships with superiors, fellow colleagues or subordinates. Companies should reflect supportive working conditions among superiors, subordinates and those with the same status. Sedarmayanti (2011)dividing the nonphysical work environment into 5 aspects that can influence employee behavior, namely: (1) Work structure, namely the extent to which the work given to him has a good work structure and organization. (2) Work responsibility, namely the extent to which workers feel that work is their responsibility and are responsible for their actions. (3) Leader's attention and support, namely the extent to which employees feel that the leadership often provides direction, confidence, attention and respect for them. (4) Cooperation between groups, namely the extent to which employees feel there is good cooperation among existing work groups. (5) Smooth communication, namely the extent to which employees feel that there is good, open and smooth communication, both between colleagues and leaders.

\section{Research methodology}

The research was conducted on employees of the Pekanbaru Eye Center Eye Hospital. The time of this research is estimated from November 2019 to completion.

Type of data

In this study, primary data comes from the results of filling out a questionnaire on the responses of respondents as a research sample on all questions given regarding the influence of organizational culture, leadership style, work discipline, knowledge management, and work environment on job satisfaction.

Population and Sample

This research was conducted at the Pekanbaru Eye Center (PBEC) Eye Hospital, the population of this study were all 81 employees of the PBEC Eye Hospital. The sampling technique used in this study was nonprobability sampling, namely saturated sampling. So all members of the population were sampled in this study, namely 81 people.

\section{Characteristics of Respondents}

This analysis aims to obtain data on the demographic characteristics of research respondents, which include gender, education, age, and years of service.

1. Characteristics of respondents based on gender and age

Characteristics of respondents based on gender and age are shown in table 2 below:

\section{Table 2 Respondents Based on Age Against Gender}

\begin{tabular}{|c|c|c|}
\hline \multirow{2}{*}{ Age } & \multicolumn{2}{|c|}{ Gender } \\
\cline { 2 - 3 } & Men & Woman \\
\hline$<25$ Years & 4 & 9 \\
\hline 25-30 years & 18 & 30 \\
\hline $31-35$ Years & 4 & 5 \\
\hline $36-40$ Years & 1 & 6 \\
\hline $41-45$ Years & 1 & 0 \\
\hline$>45$ Years & 3 & 0 \\
\hline Total & 31 & 50 \\
\hline
\end{tabular}

Source: Processed Research Data, 2020 
From table 2 it can be seen that most of the employees at the Pekanbaru Eye Center Eye Hospital are female as much as $62 \%$. This shows that most medical personnel are dominated by women, according to the World Health Organization (WHO) two-thirds of human resources in the global health sector are women.(Prastyani, 2019). Parents, family, and marriage are important factors affecting the careers of female health workers.

From table 2 it can be seen that Most of the employees of PBEC Eye Hospital are young, which is 59\% in the age range of 25-30 years. Younger employees tend to be physically strong so they are expected to work hard and generally they are not married or if they are already married, their children are still relatively few. But younger employees generally lack discipline, are less responsible and change jobs more frequently than older employees. Young employees usually have higher dreams or expectations than older employees, so older employees tend to be more satisfied.

2. Characteristics of respondents based on Education and Gender

The characteristics of respondents based on education and gender are shown in table 3 below:

Table 3 Respondents Based on Education on Gender

\begin{tabular}{|c|c|c|}
\hline \multirow{2}{*}{ Education } & \multicolumn{2}{|c|}{ Gender } \\
\cline { 2 - 3 } & Men & Woman \\
\hline High school & 8 & 5 \\
\hline D3 & 5 & 21 \\
\hline S1 & 17 & 23 \\
\hline S2 & 1 & 1 \\
\hline
\end{tabular}

Source: Processed Research Data, 2020

From the data in table 3, it can be seen that most of the employees of the Pekanbaru Eye Center Eye Hospital have an undergraduate education background as much as $49.4 \%$. $46 \%$ of female employees are S1 graduates and 42\% D3 graduates. The higher a person's education level will affect his mindset, which in turn can affect the level of job satisfaction. According to(Kenneth \& Gary, 2003) the higher the level of education, the demands on aspects of job satisfaction in the workplace will increase.

3. Characteristics of respondents based on work period and gender

The characteristics of the respondents based on work tenure and gender are shown in table 4 below:

Table 4 Respondents based on length of service and gender

\begin{tabular}{|c|c|c|}
\hline \multirow{2}{*}{ Years of service } & \multicolumn{2}{|c|}{ Gender } \\
\cline { 2 - 3 } & Men & Woman \\
\hline Under 1 Year & 7 & 7 \\
\hline 13 years old & 21 & 33 \\
\hline 4 - 6 Years & 1 & 7 \\
\hline Over 6 years & 2 & 3 \\
\hline
\end{tabular}

Source: Processed Research Data, 2020

From table 4, it can be seen that the majority of respondents have a work period of 1-3 years as much as $66.7 \%$. From this it can be seen that most of the employees of the PBEC Eye Hospital have a low tenure. A long working period will tend to make an employee feel more at home in an organization, this is because he has adapted to his environment so that an employee will feel comfortable with his job. 


\section{Evaluation of Measurement Model (OuterModel)}

Evaluation of the measurement model is used to analyze the relationship between the construct and its indicators, divided into two stages, namely convergent validity which is evaluated through indicator validity, construct reliability and average variance extracted (AVE) value and discriminant validity which is evaluated by looking at the cross loading value and then comparing the correlation between the construct and the AVE root. The analysis and evaluation of the measurement model (outer model) in the calculated-PLS algorithm results are as follows:

\section{Figure 1. the results of the calculate-PLS algorithm}

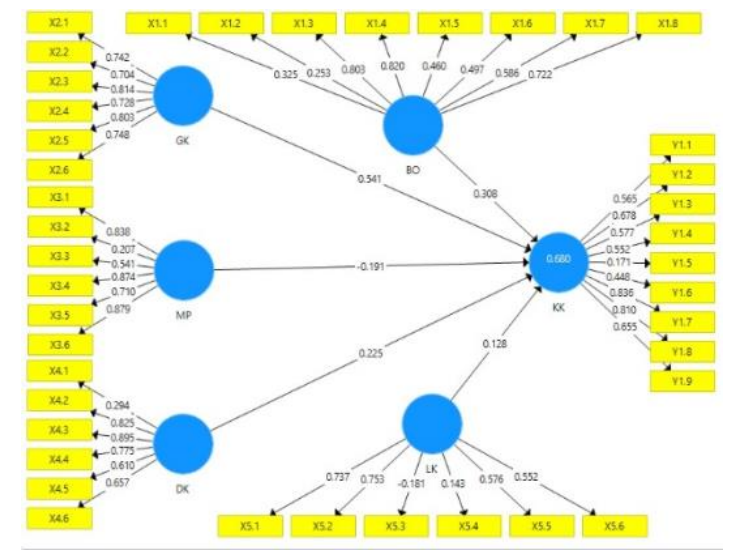

Source: Processed by researchers in 2020

\section{Reliability Test}

Model measurement is also carried out to test the reliability of a construct. Reliability test is conducted to prove the accuracy, consistency and accuracy of the instrument in measuring constructs. InsmartPLSTo measure the reliability of a construct with reflexive indicators, it can be done in two ways, namely by using Cronbach's Alpha and Composite Reliability. The use of Cronbach's alpha to test construct reliability will give a lower value (under estimate) so it is advisable to use composite reliability in testing the reliability of a construct. The composite reliability value must be more than 0.6(Ghozali \& Latan, 2015). The value of the reliability test results are as follows:

Table 5 Cronbach's Alpha Test Results

\begin{tabular}{|l|l|l|}
\hline & Cronbach's Alpha & Compossite Reliability \\
\hline BO & 0.780 & 0.871 \\
\hline NO & 0.851 & 0.898 \\
\hline MP & 0.852 & 0.895 \\
\hline DK & 0.828 & 0.882 \\
\hline LK & 0.650 & 0.851 \\
\hline KK & 0.889 & 0.947 \\
\hline
\end{tabular}

Source: 2020 research results 


\section{Evaluation of the model structure}

Testing on the structural model is evaluated by paying attention to the percentage of variance described, namely looking at the R2 value for the dependent latent variable. The magnitude of $\mathrm{R} 2$ is in the range $0<\mathrm{R} 2<1$, the closer to the value 1 , the better the model. Change in R-Square value which is a goodness-fit-model test. Used to assess the effect of the independent variable on the dependent variable whether it has a substantive effect. The R-squares values of $0.75,0.5$, and 0.25 can be concluded that the model is strong, moderate and weak. The following is the coefficient of determination (R2) of the endogenous variables shown in the table below:

Table 6 Goodness fit model test

\begin{tabular}{|l|l|l|}
\hline & $R$-Square & $R$-Square Adjusted \\
\hline Job satisfaction & 0.744 & 0.727 \\
\hline
\end{tabular}

Source: Processed Research Data, 2020

Based on table 6 , the model of the influence of organizational culture, leadership style, knowledge management, work discipline, and work environment on job satisfaction provides an R-square value of 0.744 which can be interpreted that the variability of the job satisfaction construct can be explained by the variability of the constructs of organizational culture, leadership style, management. knowledge, work discipline, and work environment by $74.4 \%$. The remaining $25.6 \%$ is explained by other variables not included in this research model.

\section{Hypothesis test}

Hypothesis testing is done by testing the significance of the influence of organizational culture, leadership style, knowledge management, work discipline, and work environment on job satisfaction through the $t$ statistical significance value. In this study using a significance level of $5 \%$ with a t-value of 1.96 . There is a significant effect if the $\mathrm{t}$-value> 1.96. The results of the $\mathrm{t}$-value obtained by the bootstrapping process are shown in table 7 as follows:

Table 7 The t-value through the bootstrapping process

\begin{tabular}{|l|l|l|l|l|}
\hline Hypothesis & $\begin{array}{l}\text { Original } \\
\text { sample }\end{array}$ & T statistics & P-Values & Conclusion \\
\hline $\mathrm{BO} \rightarrow \mathrm{KK}$ & 0.539 & 6,478 & 0,000 & Has a significant effect \\
\hline $\mathrm{NO} \rightarrow \mathrm{KK}$ & 0.461 & 5,178 & 0,000 & Has a significant effect \\
\hline $\mathrm{MP} \rightarrow \mathrm{KK}$ & $-0,315$ & 2,801 & 0.005 & Has a significant effect \\
\hline $\mathrm{DK} \rightarrow \mathrm{KK}$ & 0.224 & 1,806 & 0.072 & Has no significant effect \\
\hline LK $\rightarrow$ KK & 0.229 & 2,703 & 0.007 & Has a significant effect \\
\hline
\end{tabular}

Source: Researcher Processed Data 2020

From table 7, it can be seen that the t-value for organizational culture on job satisfaction is 6.478 ( $>1.96$ ) meaning that organizational culture has a significant effect on job satisfaction, the t-value for leadership style is 5.178 (> 1.96) meaning that leadership style has a significant influence on job satisfaction. job satisfaction, $t$-value for knowledge management 2.801 ( > 1.96) means knowledge management has a significant effect on job satisfaction, t-value for work discipline $1.806(<1.96)$ means that work discipline does not have a significant effect on job satisfaction, $t$-value for the work environment 2.703 (> 1.96) means that the work environment has a significant influence on job satisfaction. 


\section{Results and Discussion}

The discussion of research results regarding the influence of organizational culture, leadership style, knowledge management, work discipline, and work environment on job satisfaction of employees of Pekanbaru Eye Center Eye Hospital is described as follows:

\section{The Influence of Organizational Culture on Job Satisfaction}

The results of this study indicate that organizational culture has a positive and significant influence on employee job satisfaction. Strengthening organizational culture will affect employee job satisfaction, the stronger the organizational culture, the higher the employee job satisfaction. This is in line with researchAl-Sada, Al-Esmael, \& Faisal (2017), Muhajir (2014), Brahmasari \& Suprayetno (2008), and Kusumawati (2008).

Wallace (1983) in Kusumawati (2008)said that a person's job satisfaction depends on the suitability of that person's characteristics with the organizational culture. Organizational culture that grows to be strong spurs the organization towards better development. Meanwhile, job satisfaction is the general attitude of an individual to his job. The more aspects that are in accordance with the desires of the individual, the higher the job satisfaction. The more aspects that exist in individuals that are in accordance with the culture of the organization where they work, the higher their job satisfaction will be.

\subsubsection{The Effect of Leadership Style on Job Satisfaction}

The results of this study indicate that leadership style has a positive and significant effect on employee job satisfaction. The better the leadership style, the higher the level of employee job satisfaction. This is in line with researchMuhajir (2014), Al-Sada et al. (2017), and Kusumawati (2008) which states that the leadership style has a positive effect on employee job satisfaction.

Handoko (2014)states that the leadership style is how a leader can precisely direct individual goals and organizational goals. Meanwhile, job satisfaction is the general attitude of an individual to his job. The more aspects that are in accordance with the desires of the individual, the higher the job satisfaction.

The leadership style in this study is a task-oriented leadership style and relationship-oriented leadership style. The statement of the leader to prioritize his attention to the tasks that must be done by employees is the highest score for the leadership style variable followed by statements for indicators of other task-oriented leadership style whose value is greater than statements for indicators of relationship-oriented leadership style so that It can be concluded that the leadership style applied by the leadership at PBEC Eye Hospital is more likely to be a task-oriented leadership style even though the results are still not good. In the statements for the indicators of relationship-oriented leadership style, they have a low score with a bad category. A leadership style that is only task-oriented can cause stress and dissatisfaction in employees, which in turn can reduce employee retention. This requires improvement from the leaders at PBEC Eye Hospital in creating employee job satisfaction, as well as trying to apply an ideal leadership style, which is in addition to being task-oriented but does not cover the human side or keeps creating good relationships with employees.

Leaders who apply the right leadership style will be able to satisfy their subordinates so that employees become more active and their performance will be better.

\section{The Effect of Knowledge Management on Job Satisfaction}

The results of this study indicate knowledge management has a negative and significant effect on employee job satisfaction. The better or the higher the knowledge management, the lower the job satisfaction level of the employees of Pekanbaru Eye Center Eye Center. This is different from researchKordestani \& Aghazadeh (2016), Kianto, 
et.al (2016) and Kurniawan (2018) which states that knowledge management has a positive influence on job satisfaction.

Scarborough et.al (1999) in Armstrong \& Taylor (2014)defines knowledge management as any process or practice of creating, acquiring, capturing, sharing, and using knowledge to improve learning and organizational performance. So that with the increase in knowledge management can increase employee job satisfaction. In contrast to the results of this study, the higher or better knowledge management, the lower the level of employee satisfaction.

This can happen, with the higher the level of education or the higher the ability of the employees of the PBEC Eye Hospital, which causes an increase in demands from employees that cannot be fulfilled by the company, thus affecting the level of job satisfaction. There are some employees who feel that the salary they receive does not match their education level. There are some employees who feel that their abilities or competencies do not help them get opportunities for promotion. This should be a concern of the management of PBEC Eye Hospital in order to make improvements by compiling a good wage scale structure, doing job grading by applying competency standards.

\section{The Effect of Work Discipline on Job Satisfaction}

The results of this study indicate that work discipline has a positive but insignificant effect on employee job satisfaction. The increase or decrease in work discipline does not affect the level of job satisfaction of the PBEC Eye Hospital employees. The results of this study are different from the researchAziz (2016), Yunus \& Bachri (2013), and Supriyadi, et.al (2017) which states that work discipline has a significant effect on employee job satisfaction.

According to Nitisemito (1988) inSuyitno (2017)The factors that influence the emergence of work discipline vary: work goals and work abilities, exemplary leadership, welfare, justice, inherent supervision, legal sanctions, assertiveness, and human relations. Work discipline is an attitude of respecting, appreciating, and obeying the rules that apply in an organization. PBEC Eye Hospital employees consider work discipline to be a responsibility and an important thing to implement in carrying out their duties, so that the level of employee discipline does not affect the level of employee job satisfaction.

\section{The Effect of Work Environment on Employee Job Satisfaction}

The results of this study indicate the work environment has a positive and significant effect on employee job satisfaction. The better the working conditions, the higher the job satisfaction level of the employees of Pekanbaru Eye Center Eye Hospital. The results of this study are in line with the researchKurniawan (2018), Aziz (2016), and AbuAlRub, et.al (2015) which states that the work environment has a positive effect on employee job satisfaction.

Jain and Kaur (2014)states the work environment as a condition that includes physical, psychological, and social aspects that improve working conditions. A good physical and non-physical work environment is expected by employees so that they can work optimally. Thus the conditions around employees at work as best as possible are considered and maintained so that employees will feel comfortable at work so as to produce satisfaction in employees. The results showed that the work environment at PBEC Eye Hospital was still in a poor category, especially in the mental environment and hospital infrastructure. This needs attention from management in order to improve the work environment so that employees can be more enthusiastic and comfortable at work. Management can perform work rotations that are adjusted to employee competencies so that employees do not feel bored with work that tends to be monotonous, management can also create a competitive atmosphere by giving rewards to employees so that employees 
are always motivated to work and do not feel bored at work. In addition, management must also try to complete the facilities and infrastructure to support employees at work so that their work becomes lighter and the results are good and employees feel supported by management in carrying out their duties.

\section{Conclusions and suggestions \\ Conclusion}

From the research results that have been described previously, the conclusions of this study can be drawn as follows:

1. Organizational culture has a positive impact on employee job satisfaction. Every effort to improve in strengthening the organizational culture will increase employee job satisfaction. The suitability of employee characteristics with organizational culture will affect employee job satisfaction. The more aspects that exist in individual employees with organizational culture, the higher the level of job satisfaction of the employee.

2. The leadership style has a positive impact on the level of employee job satisfaction. Efforts to improve leadership style towards an ideal leadership style will increase employee job satisfaction. A leadership style that is only task-oriented can lead to employee dissatisfaction. A leadership style that is task-oriented but still pays attention to the human side while still creating good relationships with employees can increase employee job satisfaction.

3. Efforts to improve knowledge management for the better have not been able to increase the level of employee job satisfaction and even reduce employee job satisfaction. So it is necessary to provide stimulation so that increased knowledge management can increase employee job satisfaction which in turn will improve employee performance. Efforts to improve knowledge management must be balanced with efforts to implement good compensation and benefits that will increase employee job satisfaction.

4. Work discipline has no effect on employee job satisfaction. Efforts to improve work discipline for the better do not have an effect on increasing employee job satisfaction. Good work discipline can arise from exemplary towards leaders, and the existence of assertiveness in giving sanctions. Lack of assertiveness in imposing sanctions can lead to low employee discipline and job satisfaction.

5. The work environment has a positive influence on employee job satisfaction. Every effort in creating a better work environment can increase the level of employee job satisfaction. Good mental environment and work infrastructure can create a comfortable atmosphere for employees in carrying out their duties. So that this can increase employee job satisfaction.

\section{Suggestion}

From the research results and conclusions previously described, the authors provide the following suggestions:

1. In creating a strong organizational culture at the Pekanbaru Eye Center Eye Hospital, it is hoped that the management or leadership can provide a good example in its application. Management or leaders must be role models in the implementation of organizational culture.

2. In an effort to increase employee job satisfaction through a good leadership style, good communication must be built between management and employees so that a comfortable working atmosphere is created and programs issued by management receive employee support.

3. In order to increase competence as an impact of improving knowledge management to have a positive impact on employees. PBEC Eye Hospital must apply a clear wage 
structure and scale and be socialized to employees. So that employees are motivated in pursuing a career by increasing their competence

4. Discipline at PBEC Eye Hospital must be continuously improved in order to provide the best service to customers.

5. PBEC Eye Hospital should improve its facilities and infrastructure so that patients who seek treatment feel comfortable and employees who work are also comfortable at work, so that employees are expected to show their best performance.

\section{Bibliography}

AbuAlRub, R., El-Jardali, F., Jamal, D., \& Al-Rub, NA (2015). Exploring the relationship between work environment, job satisfaction, and intent to stay of Jordanian nurses in underserved areas. Applied Nursing Research, 31.

Aini, Q., Meiyanto, S., \& Meliala, A. (2004). The Relationship Between Leadership Style and Employee Commitment to Job Satisfaction at PKU Muhammadiyah Yogyakarta Hospital. JMPK, 07.

Al-Sada, M., Al-Esmael, B., \& Faisal, MN (2017). Influence of organizational culture and leadership style on employee satisfaction, commitment and motivation in the educational sector in Qatar. EuroMed Journal of Business, 12 (2).

Armstrong, M., \& Taylor, S. (2014). Armstrong's Handbook Of Human Resource Management Practice (13th ed.). UK: Ashford Color Press Ltd.

Aziz, MA (2016). The Influence of Work Motivation, Work Discipline and Work Environment on Performance Through Job Satisfaction of the Employees of the Puskesmas, Balapulang District, Tegal Regency. Multiplier.

Wake up, W. (2012). Human Resource Management. Human Resource Management.

Becerra-Fernandez, I., \& Sabherwal, R. (2015). Knowledge Manageent Systems and Processes. In Routledge. https://doi.org/10.1016/j.jclepro.2016.07.215

Bhojaraju, G. (2005). Knowledge management: Why do we need it for corporates. Malaysian Journal of Library and Information Science. https://doi.org/10.2139/ssrn.3375572

Brahmasari, IA, \& Suprayetno, A. (2008). The Influence of Work Motivation, Leadership and Organizational Culture on Employee Job Satisfaction and Its Impact on Company Performance (Case study at PT. Pei Hai International Wiratama Indonesia). Journal of Management and Entrepreneurship, 10, 124-135.

Dalkir, K. (2005). Knowledge Management In Theory And Practice. United Kingdom: Elsevier Butterworth-Heinemann.

Denison, DR, \& Mishra, AK (1995). Toward a Theory of Organizational Culture and Effectiveness. Organization Science. https://doi.org/10.1287/orsc.6.2.204

Dessler, G. (2015). Human Resource Management. In Jakarta: Four Salemba.

Dinata, MF, Bachri, AA, \& Rahmawati, R. (2018). Analysis of the Influence of Leadership Style on Job Satisfaction with Organizational Commitment as an Intevening Variable (Study on General Administration and Financial Staff at Banjarmasin Islamic Hospital. Journal of Management Insights, 6 Number 2.

Ghozali, I. (2014). Structural Equation Modeling (Edition IV). Semarang: Diponegoro University Publishing Agency.

Ghozali, I., \& Latan, H. (2015). Partial Least Square: Concepts, Techniques and Applications of SmartPLS 3.0. Semarang: Diponegoro University Publishing Agency.

Goleman, D. (2018). What makes a leader? In Military Leadership: In Pursuit of 
Excellence. https://doi.org/10.4324/9780429495007

Handoko, TH (2014). Personnel Management and Human Resources (Second). Yogyakarta: BPFE-Yogyakarta.

Hasibuan. (2018). Human Resource Management. In Human Resource Management.

Indiyati, D. (2014). The Influence of Organizational Culture and Knowledge Management on Competitive Advantage. Sociohumanities. https://doi.org/10.24198/sosiohumaniora.v16i2.5732

Isyandi, B. (2017). Human Resource Management in a Global Perspective. Depok: Rajawali Press.

Jain, R., \& Kaur, S. (2014). Impact Of Work Environment on Job Satisfaction. International Journal of Scientific and Research Publications, 4 (1), 1-8.

Kenneth, NW, \& Gary, AY (2003). Organizational Behavior and Personnel Psychology. Jakarta: PT Rineka Cipta.

Kianto, A., Vanhala, M., \& Heilmann, P. (2016). The Impact of Knowledge Management on Job Satisfaction. Journal of Knowledge Management, 20 (4), 621-636.

Kordestani, F., \& Aghazadeh, S. (2016). The study of the relationship between knowledge management and job satisfaction in nurses working in Hazrat-e Fatemeh Hospital in Tehran. Social Sciences (Pakistan), Vol. 11, pp. 3747-3752. https://doi.org/10.3923/sscience.2016.3747.3752

Kristinawati, D., \& Tjakraatmadja, JH (2018). How Do Dynamic Capabilities and Knowledge Management Affect Company Performance? : A Conceptual Model Building. Matrix: Journal of Management, Business Strategy and Entrepreneurship. https://doi.org/10.24843/matrik:jmbk.2018.v12.i02.p02

Kuncoro, mudrajad. (2010). Quantitative methods: theory and application for business and economics. In System.

Kurniawan, F. (2018). The Influence of Knowledge Management and Work Environment on Employee Performance with Job Satisfaction as an Intervening Variable (Study on Education Personnel at X University of Yogyakarta). Indonesian Islamic University.

Kusumawati, R. (2008). Analysis of the Influence of Organizational Culture and Leadership Style on Job Satisfaction to Improve Employee Performance (Case Study at Roemani Hospital Semarang). Diponegoro University.

Lodge, M., \& Gill, D. (2011). Toward a New Era of Administrative Reform? The Myth of Post-NPM in New Zealand. Governance. https://doi.org/10.1111/j.14680491.2010.01508.x

Luthans, F. (2012). Organizational Behavior: An Evidence - Based Approach. New York: The McGraw-Hill Companies Inc.

Machasin. (2018). Organizational behavior. Pekanbaru: UR Press.

Mangkunegara, AP (2013). Human Resource Management of the Company. Bandung: Rosdakarya.

Mas'ud, F. (2004). Organizational Diagnostic Survey Concepts and Applications. Semarang: BP-UNDIP.

Muhajir, I. (2014). Analysis of the Influence of Leadership Style and Organizational Culture on Job Satisfaction to Improve Employee Performance. Indonesian Journal of Marketing Science, XIII (2), 170-188.

Nanditya, Mansur, M., \& Huda, S. (2014). Factors Shaping Job Satisfaction of Health Workers in Hospitals. Medical Journal of Brawijaya, 28.

Nitisemito, \& AS (2001). Personnel Management. In Bogor: Ghalia Indonesia.

Prastyani, AW (2019). Research by female health workers: the squeeze of gender roles has a profound effect on their careers. Retrieved from www.theconversation.com 
Rivai, V. (2013). Human Resource Management. Human Resource Management For Companies From Theory To Practice.

Rivai, V., \& Mulyadi, D. (2012). Leadership and Organizational Behavior. In Leadership and Organizational Behavior.

Robbins, SP, \& Coulter, M. (2013). Management Volume 2 (10th ed.). Jakarta: Erlangga.

Robbins, SP, \& Judge, TA (2015). Organizational Behavior (16th ed.). Jakarta: Four Salemba.

Trumpet. (2007). Knowledge Management. Jakarta: Rajawali Press.

Schein, EH (2009). The Corporate Culture Survival Guide. In John Wiley Trade.

Sedarmayanti. (2011). Work Procedure and Work Productivity. In Bandung, CV Mandar Maju.

Now, U., \& Bougie, R. (2017). Research Methods for Business Approach and Skills Development (Edition $6 \mathrm{Bu}$ ). Jakarta: Four Salemba.

Solihin, M., \& Ratmono, D. (2013). SEM-PLS Analysis with WarpPLS 3.0: For Nonlinear Relationships in Social and Business Research (Edition 1). Yogyakarta: ANDI.

Sudan, Y. (2016). The Influence of Motivation and Work Discipline on Job Satisfaction and Its Implications on Nurse Performance in RSUD Sumedang Regency.

Sugiyono. (2017). Statistics For Research. Bandung: Alfabeta.

Supriyadi, MF, Priadana, S., \& Setia, BI (2017). Compensation and Work Discipline on Employee Satisfaction at Kampoeng Daun Restaurant. Journal of Business and Management Research, 10, 24-33.

Suyitno. (2017). Effect of Competence, Satisfaction and Discipline on Performance of Employees in the Office of Women Empowerment and Family Planning of West Papua. Asian Social Science, 13.

Timpe, AD (2002). Motivating Employees (Budidharmo, Ed.). Jakarta: Elex Media Competindo.

Vuksic, VB, \& Stemberger, MI (2012). The Impact Of Knowledge Management On Organizational Performance The Impact Of Knowledge Management On Organizational Performance. Economic And Business Review.

Wang, S., \& Noe, RA (2010). Knowledge sharing: A review and directions for future research. Human Resource Management Review. https://doi.org/10.1016/j.hrmr.2009.10.001

Wibowo, MA, \& Putra, YS (2016). The Influence of Motivation and Organizational Culture on Job Satisfaction and Its Implications for Employee Performance at the Salatiga General Hospital (RSU). Home, 9.

Wuryanto, E. (2010). The Relationship between Work Environment and Individual Characteristics with Job Satisfaction of Nurses at the Tugurejo Regional General Hospital, Semarang. Faculty of Nursing.

Yunus, A., \& Bachri, AA (2013). The Influence of Work Discipline, Motivation, Leadership on Job Satisfaction of Study Employees at Pt. Bumi Barito Utama, Banjarmasin Branch. Journal of Management Insights, 1.

Zhou, AZ, \& Fink, D. (2003). The intellectual capital web: A systematic linking of intellectual capital and knowledge management. Journal of Intellectual Capital. https://doi.org/10.1108/14691930310455379 